\title{
Küçük hücreli dışı akciğer kanserlerinde endoglin, CD31 ve VEGFR2 ile saptanan mikrodamar yoğunluğu ve sağkalıma etkisi
}

\author{
Microvessel density determined by endoglin, CD31 and VEGFR2 and its effect on \\ survival in non-small cell lung cancers
}

Hülya Çetin, Ferda Bir, Sevin Başer Öncel, Argün Kış, Yaşar Enli

Gönderilme tarihi:29.04.2021

Kabul tarihi:22.09.2021

\section{Öz}

Amaç: Gün geçtikçe artmakta olan kanser çağımızın ciddi global sağlık sorunudur ve akciğer kanseri tüm dünyada toplam kanser sayısı içerisinde en sık görülen kanserdir. Tümörlerin gelişiminde ve metastazında anjiogenez önemli bir rol oynamaktadır. Farklı endotel belirteçleri ile hesaplanan mikrodamar yoğunluğunun (MY) bazı tümörlerde kötü prognoz ve ileri evre ile ilişkili olduğu gösterilmiştir ve buradan hareketle metastazı öngörebileceği ileri sürülmüştür. Çalışmamızda, küçük hücreli dışı akciğer kanserlerinde (KHDAK) MY'yi immünohistokimyasal olarak endoglin, CD31 ve VEGFR2 ile tespit edip, serum endoglin seviyesi ile ilişkilendirerek sonuçlarımızı akciğer tümörlerinin progresyonu ile karşılaştırmayı amaçladık.

Gereç ve yöntem: Çalışmamızda 36 skuamöz hücreli karsinom (SHK) ve 36 adenokarsinom olmak üzere toplam 72 akciğer dokusunda anjiogenik faktörlerden endoglin (CD105), CD31, VEGFR2'nin ekspresyonu immünohistokimyasal olarak incelendi. Primer akciğer kanseri tanısı alan gönüllü 26 kişinin ve 26 sağlıkı gönüllüden alınan serumlarda endoglin seviyesi Elisa yöntemi ile tespit edildi.

Bulgular: Endoglinin aktive edilmiş endotelyal hücreleri için daha büyük bir afiniteye sahip olduğunu gözledik. Her iki tümör tipinde CD31 nonspesifik boyanma göstermiş MY daha zor tespit edilmiştir. VEGFR2 boyalı kesitlerde tümör içinde ve dışındaki damar duvarlarında yaygın pozitiflik saptandı. Serum endoglin seviyesinin KHDAK hastaları ile kontrol grubu arasında istatistiksel olarak anlamlı olmadığı tespit edildi. Immünohistokimyasal olarak endoglin, CD31 ve VEGFR2 ekspresyonu ile sağkalım arasında istatistiksel olarak anlamlılık mevcut değildi.

Sonuç: Çalışmamız sonucunda KHDAK'de immünohistokimyasal olarak spesifik boyanan endoglinin SHK ve adenokarsinom tipli hastalarda anjiogenezin değerlendirilmesinde daha iyi bir belirteç olabileceğini düşünmekteyiz.

Anahtar kelimeler: Küçük hücreli dışı akciğer kanseri (KHDAK), anjiogenez, endoglin, CD31, VEGFR2.

Çetin H, Bir F, Başer Öncel S, Kış A, Enli Y. Küçük hücreli dışı akciğer kanserlerinde endoglin, CD31 ve VEGFR2 ile saptanan mikrodamar yoğunluğu ve sağkalıma etkisi. Pam Tıp Derg 2022;15:69-76.

\begin{abstract}
Purpose: Lung cancer is the most common cancer in the world. Angiogenesis plays an important role in the development and metastasis of tumors. It has been shown that microvessel density (MY) calculated with different endothelial markers is associated with poor prognosis and advanced stage in some tumors. In our study, we aimed to detect MY immunohistochemically with endoglin, CD31 and VEGFR2 in non-small cell lung cancers (KHDAK), correlate it with serum endoglin level and compare our results with the progression of lung tumors.

Materials and methods: In our study, the expression of endoglin (CD105), CD31, VEGFR2 from angiogenic factors was examined immunohistochemically in a total of 72 lung tissues, 36 of which were squamous cell carcinomas (SHK) and 36 were adenocarcinomas. Endoglin level was determined by Elisa method from blood taken from 26 volunteers and 26 healthy volunteers diagnosed with primary lung cancer.

Results: We observed that endoglin has a greater affinity for activated endothelial cells. Both tumor types showed nonspecific CD31 staining, and MY was difficult to determine. On VEGFR2 stained sections, diffuse positivity was detected in the vessel walls inside and outside the tumor. It was found that the blood endoglin level was not statistically significant between the KHDAK and the control group. Immunohistochemically, there was no difference statistically significant between endoglin, CD31 and VEGFR2 expression and survival.

Conclusions: As a result of our study, we think that immunohistochemically specific stained endoglin in KHDAK may be a better marker in the evaluation of angiogenesis in patients with both SHK and adenocarcinoma types.
\end{abstract}

Hülya Çetin, Prof. Dr. Pamukkale Üniversitesi, Histoloji ve Embriyoloji Anabilim Dalı, Denizli, Türkiye, e-posta: hcsorkun@pau.edu.tr (https:// orcid.org/0000-0001-8731-0631) (Sorumlu Yazar)

Ferda Bir, Prof. Dr. Pamukkale Üniversitesi, Tıbbi Patoloji Anabilim Dalı, Denizli, Türkiye, e-posta: fbir@pau.edu.tr (https://orcid.org/0000-00023766-4383)

Sevin Başer Öncel, Prof. Dr. Pamukkale Üniversitesi, Göğüs Hastalıkları Anabilim Dalı, Denizli, Türkiye, e-posta: sevinbaser@pau.edu.tr (https://orcid.org/0000-0002-5538-7754)

Argün Kış, Öğr. Gör. Pamukkale Üniversitesi, Göğüs Cerrahisi Anabilim Dalı, Denizli, Türkiye, e-posta: akis@pau.edu.tr (https://orcid.org/00000001-9903-1576)

Yaşar Enli, Prof. Dr. Pamukkale Üniversitesi, Tıbbi Biyokimya Anabilim Dalı, Denizli, Türkiye, e-posta: yenli@pau.edu.tr (https://orcid.org/00000001-50803192) 
Key words: Non-Small cell lung cancer, angiogenesis, endoglin, CD31, VEGFR2.

Cetin H, Bir F, Baser Oncel S, Kis A, Enli Y. Microvessel density determined by endoglin, CD31 and VEGFR2 and its effect on survival in non-small cell lung cancers. Pam Med J 2022;15:69-76.

\section{Giriş}

Akciğer kanseri tüm dünyada en sık görülen kanser olup, özellikle sigara kullanımının artmasıyla beraber tüm dünyada toplum sağığını tehdit eden, önemli bir hastalık haline gelmiştir. Birçok tümörün gelişiminde ve metastazında önemli bir rol oynayan anjiogenez akciğer tümörlerinde de prognostik belirteç olarak kullanılmaktadır [1-4]. Farklı endotel belirteçleri ile hesaplanan mikrodamar yoğunluğunun (MY) akciğer tümörleri de dahil bazı tümörlerde kötü prognoz ve ileri evre ile ilişkili olduğu gösterilmiş ve buradan hareketle metastazı öngörebileceği ileri sürülmüştür [5].

Endoglin, 180 kDa'lık tip-I transmembran glikoproteindir ve Transforming Growth Factor (TGF) - $\beta$ süper ailesinin ligandları için bir koreseptör olarak işlev görür. Endoglin, ağırlıklı olarak aktive edilmiş endotelyal hücreler tarafından eksprese edilir ve anjiyogenezde çok önemli bir rol oynar [6]. Aynı zamanda dolaşımdaki serum endoglin düzeyinin de farklı tümörlerde metastatik hastalığın varlığı ile korele olduğu belirtilmektedir [6-10].

CD31, immünglobulin süper ailesinin trombositler ve endotel hücrelerinin yanı sıra lökositler ve T hücrelerinde eksprese edilen 130 kDa'lık bir transmembran glikoprotein üyesidir [11]. Vasküler gelişim [12, 13], vasküler endotel bariyer fonksiyonunun sürdürülmesinde rol oynar [14].

Proanjiyogenik faktör olan VEGF perisitlerden ve myeloid hücrelerden salınır ve reseptörlerine (VEGFR1-VEGFR2) bağlanarak endotelyal farklanmayı ve yeni kan damarı oluşumunu uyarır. VEGFR2 aktivasyonunun artmış vasküler geçirgenlikte ve endotel hücre proliferasyonu, migrasyonu ve istilasında önemli bir rol oynadığı iyi bilinmektedir $[15,16]$.

$\mathrm{Bu}$ çalışmada, küçük hücreli dışı akciğer kanserlerinde (KHDAK) MY'yi immünohistokimyasal olarak anjiogenik faktörlerden endoglin, CD31 ve VEGFR2 ile tespit edip, serum endoglin seviyesi ile ilişkilendirerek sonuçlarımızı akciğer tümörlerinin progresyonu ile karşılaştırmayı amaçladık.

\section{Gereç ve yöntem}

2012-2018 yılları arasında Pamukkale Üniversitesi Tıp Fakültesi Tıbbi Patoloji Anabilim Dalı'nda tanı almış, evreleri I-IV arasında değişen preoperatif antikanser tedavisi almamış, 36 skuamöz hücreli karsinom (SHK) ve 36 adenokarsinom olmak üzere toplam 72 akciğer karsinomu olgusu incelendi. Olguların histolojik sınıflandırması Dünya Sağlık Örgütü'nün (DSÖ) 2015 sınıflamasına göre yapıldı [17].

Olgularımızdan Şubat 2017-Eylül 2018 tarihleri arasındaki dönemde Göğüs Hastalıkları Polikliniği'ne müracaat ederek primer akciğer kanseri tanısı alan gönüllü 26 kişiden (12 SHK+14 adenokarsinom) ve kanser tanısı almamış, kronik bir hastalığı olmadığını beyan eden ve kontrol grubunu oluşturan 26 gönüllüden onay alınarak, alınan kan serumlarında endoglin seviyeleri Sandwich Assay İmmunoassay [YLBIONT CAT no: YLA0768HU (Human endoglin ELISA KIT)] kiti kullanılarak Elisa yöntemi ile saptandı. Çalışmamız, Pamukkale Üniversitesi Girişimsel Olmayan Klinik Araştırmalar Etik Kurulu tarafından onaylanmış ve Pamukkale Üniversitesi, Bilimsel Araştırma Projeleri Koordinasyon Birimi tarafından (Proje No:2017SABE003) desteklenmiştir.

İmmünohistokimyasal inceleme için tümör dokusunu en iyi yansıtan birer örnek belirlendi. Seçilen parafin bloklardan pozitif yüklü lamlara her olgu için endoglin (BioGenex, predilue), CD31 (CELL MARQUE+ RabMAb Technology from Abcam EP78), VEGFR2 (İnvitrogen 1/250 dilüsyon) antikorları çalışılmak üzere birer adet 3 mikronluk kesitler alındı. Alınan doku örnekleri deparafinizasyon için $50^{\circ} \mathrm{C}$ 'de bir gece etüvde bekletildi. Daha sonra otomatik olarak VENTANA, Benchmark XT cihazı yardımı ile boyandı. Boyama işleminden sonra yıkama yapılıp, sırasıyla alkol ve ksilen serilerinden geçirildikten sonra entellan ile kapatıldı.

İmmünohistokimyasal yöntemle CD31, endoglin ve VEGFR2 boyadığımız tümör kesitleri Olympus BX51 ışık mikroskobu kullanılarak, küçük büyütmelerde (40X ve 100X) tarandı, neovaskülarizasyonun yoğun olduğu 3 farklı alan seçildi. $400 X$ büyütmede tümör hücrelerinden 
ve diğer bağ dokusu elemanlarından ayrı duran, kahverengi boyalı tek bir endotel hücresi ya da birbiriyle bağlantılı endotel hücre kümeleri, lümen oluşturup oluşturmadığına bakılmaksızın, sayılabilen bir mikrodamar olarak kabul edildi. Kas tabakası olan damarlar, yeni damar olarak kabul edilmediğinden sayıma dahil edilmedi [18]. MY, 3 araştırmacı tarafından 3 farklı alanda sayılan damarların ortalaması alınarak hesaplandı. Ayrıca tümör hücrelerinde kısmi ya da diffüz sitoplazmik VEGFR2 boyanması olan tümörler pozitif kabul edildi. Sitoplazmik pozitif olan tümör hücreleri yoğunluğu yüzde (\%) oran olarak değerlendirildi.

Çalışmamızdaki istatistiksel veriler SPSS 24.0 paket programı kullanılarak sürekli değişkenler ortalama \pm standart sapma ve kategorik değişkenler sayı ve yüzde olarak ifade edildi. Bağımsız grup farklılıkların karşılaştırılmasında Mann-Whitney $U$ testi kullanıldı. Kategorik değişkenler arasındaki farklılıklar ise Ki kare analizi ile değerlendirildi. Sağkalım analizlerinde Kaplan Meier eğrileri kullanılarak bağımsız grupların sağkalım farkılıkları için Logrank yöntemi uygulandı. Tüm analizlerde $p<0,05$ istatistiksel olarak anlamlı kabul edildi.

\section{Bulgular}

2015 "International Association for the Study of Lung Cancer" (8th Edition of the TNM Classification for Lung Cancer) kriterlerine göre olguların evrelere göre dağılımı: Evre IA1 4 hasta $(\% 5,6)$, evre IA2 10 hasta $(\% 13,9)$, evre IA3 17 hasta $(\% 23,6)$, evre IB 8 hasta $(\% 11,1)$, evre IIA 2 hasta $(\% 2,8)$, evre IIB 21 hasta $(\% 29,2)$, evre IIIA 9 hasta $(\% 12,5)$, evre IVB 1 hasta $(\% 1,4)$ olarak tespit edilmiştir.

Olguların yaş ortalamalarının SHK grubunda $66,16 \pm 9,28$, adenokarsinom grubunda $65,36 \pm 11,78$ olduğu saptandı. Tüm olguların klinik izlem bilgilerine ulaşıldı. Bu 72 olgunun klinik izlem süreleri minimum 2 ay, maksimum 72 ay olup, izlenen hastaların 50'sinin izlem süresi sonunda hayatta olduğu, 22'sinin ise hayatını kaybettiği görüldü. Hastaların 20'sinde tümörün nüks ettiği saptandı.

SHK grubundaki 36 hastanın 14 tanesi izlem sonunda hayatını kaybetti. SHK grubundaki hastaların ortalama sağkalım süresinin $54,9 \pm 5,6$ ay olduğu tespit edildi. Adenokarsinom grubundaki 36 hastanın 8 tanesi izlem sonunda hayatını kaybetti. Adenokarsinom grubundaki hastaların ortalama sağkalım süresi $62,25 \pm 6,3$ ay olarak bulundu. Tümör tipi ile ortalama sağkalım süresi arasında istatistiksel olarak anlamlı ilişki görülmedi $(p>0,05)$ (Tablo 1).

İmmünohistokimyasal olarak endoglin ile saptanan (Şekil 1) ortalama damar sayısının SHK grubunda 11,33 $\pm 4,01$, adenokarsinom grubunda ise $9,56 \pm 2,66$ olduğu tespit edildi. İki gruba ait damar sayıları birbiri ile karşılaştırıldığında bu ilişki istatistiksel olarak anlamlı bulundu $(p<0,05)$ (Tablo 2).

CD31 antikoru ile immünohistokimyasal olarak saptanan ortalama damar sayısı adenokarsinom grubunda 16,5 $\pm 4,99$, SHK grubunda 15,28 $\pm 5,62$ olarak bulundu. İki grup arasında istatistiksel anlamlılık mevcut değildi (Şekil 1) (Tablo 2).

İmmünohistokimyasal olarak VEGFR2 uygulanan hem adenokarsinom hem de SHK grubuna ait doku kesitlerinde tümör içinde ve dışında bulunan damar duvarlarında yaygın olarak pozitiflik saptandı (Şekil 1). Tümör bölgesinde VEGFR2 pozitiflik gösteren damar sayıları SHK grubunda ortalama $22,37 \pm 6,73$ ve adenokarsinom grubunda 23,09 $\pm 7,92$ olduğu görüldü. Gruplar arasında istatistiksel anlamlılık mevcut değildi $(p>0,05)$ (Tablo 2). Aynı zamanda adenokarsinom grubundaki 13 hastanın ve SHK grubundaki6hastanın dokukesitlerindeVEGFR2 tümör hücrelerinde de sitoplazmik olarak pozitif boyanma gösterdi (Şekil 1). Sitoplazmik pozitif olan tümör hücreleri yoğunluğu adenokarsinom grubu hastalarda ortalama \%8,33 $\pm 19,09$, SHK grubu hastalarda ortalama $\% 0,97 \pm 3,69$ olarak bulundu. İstatistiksel olarak iki farklı tümör tipinde tümör hücrelerinde sitoplazmik boyanma yoğunluğu arasındaki ilişki karşılaştırıldığında adenokarsinom grubu lehine anlamlı bulundu $(p=0,016)$.

İmmunohistokimyasal olarak endoglin, CD31 ve VEGFR2 ekspresyonu klinikopatolojik veriler olan hasta yaşı, cinsiyet, tümörün hangi akciğerde lokalize olduğu, tümör tipi, tümör çapı, anjiolenfatik invazyon, plevral invazyon, lenf nodu metastazı, uzak metastaz, evre ve genel sağkalım ile karşılaştırıldığında istatistiksel olarak anlamlı ilişki bulunamadı $(p>0,05)$.

Nüks görülen hastaların 14'ü SHK, 6'sı adenokarsinom morfolojisindeydi. SHK grubunda hastalıksız yaşam süresi ortalama 
Tablo 1. Olguların klinikopatolojik özelliklere göre dağılımı

\begin{tabular}{|c|c|c|c|c|c|}
\hline & & $\begin{array}{l}\text { Squamöz } \\
\mathrm{n}(\%)\end{array}$ & $\begin{array}{l}\text { Adenokarsinom } \\
\mathrm{n}(\%)\end{array}$ & $\begin{array}{l}\text { Toplam } \\
\text { n (\%) }\end{array}$ & $p$ \\
\hline Cinsiyet & $\begin{array}{l}\text { Erkek } \\
\text { Kadın }\end{array}$ & $\begin{array}{l}35(97,22) \\
1(2,78)\end{array}$ & $\begin{array}{l}26(72,22) \\
10(27,78)\end{array}$ & $\begin{array}{l}61(84,72) \\
11(15,28)\end{array}$ & $0,003^{*}$ \\
\hline Lokalizasyon & $\begin{array}{l}\text { Sağ } \\
\text { Sol }\end{array}$ & $\begin{array}{l}21(58,33) \\
15(41,67)\end{array}$ & $\begin{array}{l}21(58,33) \\
15(41,67)\end{array}$ & $\begin{array}{l}42(58,33) \\
30(41,67)\end{array}$ & 1 \\
\hline Tümör çapı & $\begin{array}{l}<3 \mathrm{~cm} \\
\geq 3 \mathrm{~cm}\end{array}$ & $\begin{array}{l}18(50) \\
18(50)\end{array}$ & $\begin{array}{l}22(61,11) \\
14(38,89)\end{array}$ & $\begin{array}{l}40(55,56) \\
32(44,44)\end{array}$ & 0,343 \\
\hline Anjiyolenfatik invazyon & $\begin{array}{l}(+) \\
(-)\end{array}$ & $\begin{array}{l}22(61,11) \\
14(38,89)\end{array}$ & $\begin{array}{l}17(47,22) \\
19(52,78)\end{array}$ & $\begin{array}{l}39(54,17) \\
33(45,83)\end{array}$ & 0,237 \\
\hline Plevral invazyon & $\begin{array}{l}(+) \\
(-)\end{array}$ & $\begin{array}{l}10(27,8) \\
26(72,2)\end{array}$ & $\begin{array}{l}19(52,8) \\
17(\% 7,2)\end{array}$ & $\begin{array}{l}29(40,3) \\
43(59,7)\end{array}$ & $0,031^{*}$ \\
\hline Lenf nodu metastazı & $\begin{array}{l}(+) \\
(-)\end{array}$ & $\begin{array}{l}12(33,3) \\
24(66,7)\end{array}$ & $\begin{array}{l}8(22,22) \\
28(77,78)\end{array}$ & $\begin{array}{l}20(27,8) \\
52(72,2)\end{array}$ & 0,293 \\
\hline Uzak metastaz & $\begin{array}{l}(+) \\
(-)\end{array}$ & $\begin{array}{l}12(33,33) \\
24(66,67)\end{array}$ & $\begin{array}{l}10(27,77) \\
26(72,23)\end{array}$ & $\begin{array}{l}22(30,6) \\
50(69,4)\end{array}$ & 0,485 \\
\hline Evre & $\begin{array}{l}(\mathrm{I}, \text { II }) \\
(\mathrm{III}, \mathrm{IV})\end{array}$ & $\begin{array}{l}30(83,3) \\
6(16,7)\end{array}$ & $\begin{array}{l}32(88,9) \\
4(11,1)\end{array}$ & $\begin{array}{l}62(86,1) \\
10(13,9)\end{array}$ & 0,496 \\
\hline Lokal nüks & $\begin{array}{l}(+) \\
(-)\end{array}$ & $\begin{array}{l}14(38,9) \\
22(61,1)\end{array}$ & $\begin{array}{l}6(16,7) \\
30(83,3)\end{array}$ & $\begin{array}{l}20(27,8) \\
52(72,2)\end{array}$ & $0,035^{*}$ \\
\hline Sağkalım & $\begin{array}{l}\text { Eks } \\
\text { Yaşıyor }\end{array}$ & $\begin{array}{l}14(38,9) \\
22(61,1)\end{array}$ & $\begin{array}{l}8(22,2) \\
28(77,8)\end{array}$ & $\begin{array}{l}22(30,6) \\
50(69,4)\end{array}$ & 0,125 \\
\hline
\end{tabular}

${ }^{*} p<0,05$ istatistiksel olarak anlamlı farklılık; Ki-kare analizi

Tablo 2. İmmünohistokimyasal belirteçlere göre grupların ortalama mikrodamar sayıları

\begin{tabular}{llll}
\hline Tümör tipi & Endoglin (CD105) & CD31 & VEGFR2 \\
\hline SHK $(\mathrm{n}=36)$ & $11,33 \pm 4,01$ & $15,28 \pm 5,62$ & $22,37 \pm 6,73$ \\
Adenokarsinom $(\mathrm{n}=36)$ & $9,56 \pm 2,66$ & $16,50 \pm 4,99$ & $23,09 \pm 7,92$ \\
& $p=0,039^{*}$ & $p=0,179$ & $p=0,192$ \\
\hline
\end{tabular}

${ }^{*} \mathrm{p}<0,05$ istatistiksel olarak anlamlı farklılık; Ki-kare analizi
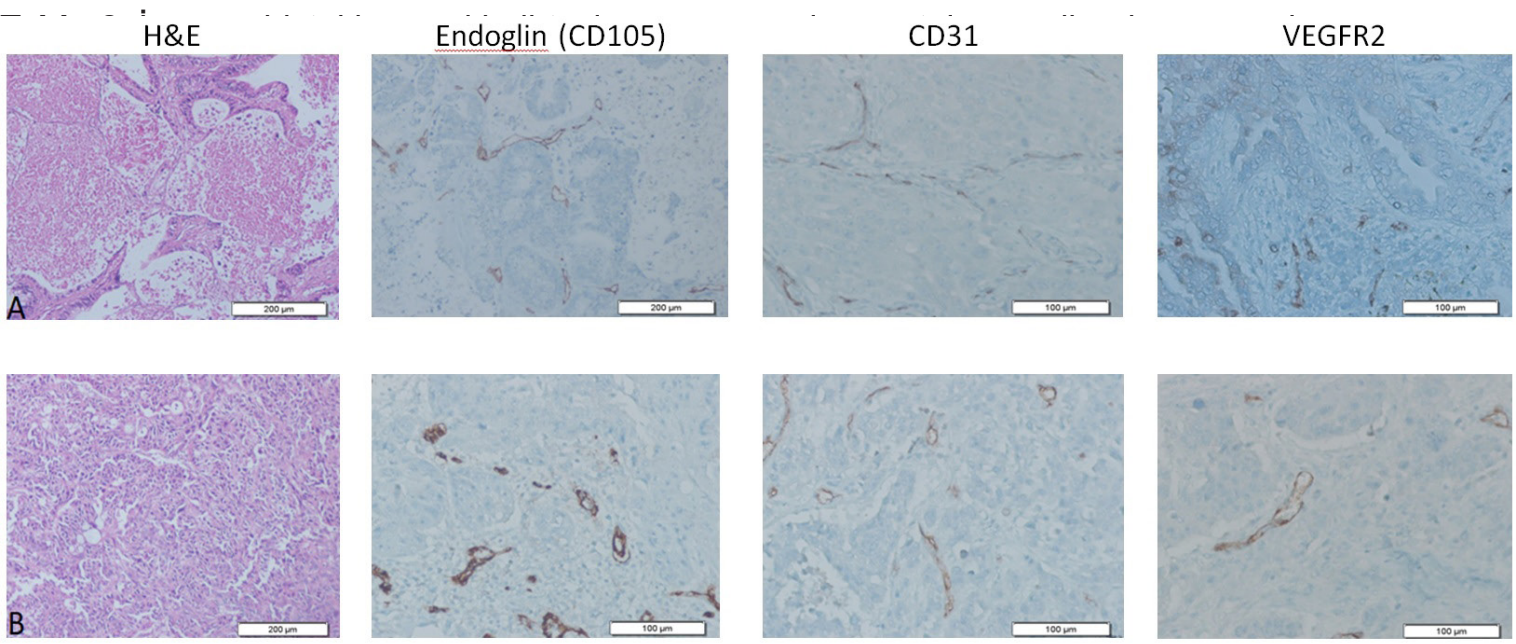

Şekil 1. Adenokarsinom (A) ve SCC (B) dokularda endoglin (CD105), CD31 ve VEGFR2 ekspresyonu 
$51,94 \pm 6,40$ ay, adenokarsinom grubunda ortalama $70,67 \pm 5,84$ ay olarak tespit edildi. Hastalıksız yaşam süresinin SHK grubunda istatistiksel olarak anlamlı derecede daha kısa olduğu görüldü $(p=0,035)$. Çalışmamızda kullandığımız immünohistokimyasal belirteçler ile hastalıksız yaşam süresi arasındaki ilişki incelendiğinde istatiksel olarak anlamlı sonuç bulunamadı $(p>0,05)$.

Serum endoglin düzeyi saptanan gönüllü 26 hastanın yaş ortalaması $62,12 \pm 7,61$, kontrol grubunun yaş ortalaması $52,23 \pm 13,47$ 'dir. Serum endoglin seviyesi hasta grubunda ortalama $12,42 \pm 10,6 \mu \mathrm{mol} / \mathrm{L}$, kontrol grubunda ortalama $12,61 \pm 13,12 \mu \mathrm{mol} / \mathrm{L}$ olarak saptand. Serum endoglin seviyesi açısından KHDAK hastaları ve kontrol grubu arasında istatistiksel olarak anlamlı ilişki bulunamadı $(p>0,05)$.

\section{Tartışma}

Akciğer kanseri erkeklerde dünyada en sık görülen malign tümördür. Akciğer tümörleri içinde \%90-95 oranla en sık akciğer karsinomları görülür. İnsidans cinsiyete göre degişiklik gösterir. DSÖ'ye göre en sık görülen karsinom olan SHK erkeklerde \%44'lük bir oran gösterirken, kadınlarda bu oran \%25'tir. Adenokarsinomlarda ise oran tersine dönerek, erkeklerde \%28'lik bir oranda kalırken, kadınlarda \%42'lere ulaşır [19]. Literatürdeki bazı bilgilere göre bu oranlar değişiklik gösterir ve her iki cinste adenokarsinom en sık görülen akciğer kanseri olarak belirtilir [20]. Türkiye'de yapılan çalışmalara göre, SHK \%41,1 ile en sık görülen akciğer kanseri tipini oluştururken, adenokarsinom ise \%25,6 ile ikinci sırada yer almaktadır. Cinsiyet göz önünde bulundurulduğunda, kadınlarda \%14 ile en sık adenokarsinom, erkeklerde $\% 36,1$ ile en sık SHK görüldüğü rapor edilmiştir [21, 22]. Bizim çalışmamızda tüm hastaların $\% 84,72$ 'sini erkeklerin oluşturduğu ve kadın hastalara oranla istatistiksel bakımdan anlamlı derecede yüksek olduğu görülmüştür. Hastalarımızın toplam 11 kişisi kadınlardan oluşmakta ve 10 kadında adenokarsinom, 1 kadında SHK tespit edilmiştir. Kadınlarda adenokarsinom tipi akciğer kanserinin SHK"e göre daha fazla olduğu görülmüştür.

Solid tümörlerin gelişiminde ve metastazında anjiogenez önemli bir rol oynamaktadır. MY farklı endotel belirteçleri ile hesaplandığında bazı tümörlerde kötü prognoz ve ileri evre ile ilişkili olduğu gösterilmiş ve metastazı öngörebileceği ileri sürülmüştür [23].

CD31, CD34 ve endoglin intratümöral damarların yoğunluğunu tespit etmek için endotelyal antijen olarak kullanılmış ve endoglinin KHDAK'de anjiyogenezin değerlendirilmesinde CD34 ve CD31'den daha üstün olduğu ifade edilmiştir [24]. Endoglin, tümör içinde veya çevresinde yüksek hassasiyete sahip küçük damarları boyarken, neoplastik olmayan dokudaki kan damarlarını boyamadığı veya sadece zayıf boyadığı ifade edilmiştir. Buna karşılık CD31'in ise tüm kan damarlarını ayrım gözetmeden boyadığı görülmüştür $[25,26]$. Glioblastomlu hastalar üzerinde yapılan çalışmada da benzer sonuca ulaşılmış, endoglinin glioblastomadaki anjiyogenezin değerlendirilmesinde CD31'e göre daha spesifik ve hassas bir belirteç olduğu gösterilmiştir [27]. Çalışmamızda CD31'in nonspesifik boyanma göstermesi MY'nin tespit edilebilmesini zorlaştırmıştır. Söz konusu nonspesifik boyanma uyguladığımız teknik ya da kullandığımız ticari kit kaynaklı olabilir. CD31 ile tespit edilen ortalama MY, adenokarsinom ve SHK grupları arasında istatistiksel olarak anlamlı farklılık göstermemiştir. Bununla birlikte endoglin ekspresyonu ile tespit edilen her iki gruba ait ortalama MY karşılaştırıldığında SHK grubunda istatistiksel olarak daha fazla olduğu görülmüştür. SHK grubundaki hastaların ortalama sağkalım süresinin ve hastalıksız yaşam süresinin adenokarsinom grubuna göre daha kısa olduğu gözlenmiştir. Hastalıksız yaşam süresi SHK grubunda istatistiksel olarak anlamlı daha kısa olmasına rağmen ortalama sağkalım süresinde istatistiksel olarak anlamlılık mevcut değildir. Bu durum endoglinin KHDAK neoananjiyogenezi için daha spesifik bir belirteç olarak kullanılabileceğini düşündürmektedir.

Akciğer kanserinde VEGFR2 ekspresyonunu bildiren çalışmalar olsa da [28-32], bu ifadenin klinik öneminin belirsizliğini koruduğu [33, 34], bazı çalışmalarda VEGFR2'nin KHDAK hücrelerinde eksprese edilmediği de bildirilmiştir [35]. Çalışmamıza dahil edilen KHDAK'li olgulara ait dokularda VEGFR2 boyanması SHK tip hastaların 6'sında, adenokarsinomlu hastaların 13'ünde pozitiftir. KHDAK'li hastalar üzerinde yapılan çalışmada yüksek VEGF ve endoglin ekspresyonunun hastalarda kötü 
prognoz, düşük sağkalım ile korele olduğu belirtilmiştir [24]. Kolorektal kanserli hastalarda da endoglinin aşırı ekspresyonunun hastalığın ilerlemesi ile pozitif ilişkili olduğu bildirilmiştir [26]. Devery ve ark.'nın [36] çalışması sonucunda, tümör hücreleri yüksek seviyelerde VEGFR2 eksprese eden KHDAK'li hastaların hem anjiyogenez hem de artan proliferasyon yoluyla tümör büyümesine sahip olabileceği belirtilmiştir. Çalışmamızda VEGFR2 hem tümör içi hem de tümör dışı bölgede yer alan damar duvarlarında pozitiflik göstermiştir. Bununla birlikte bazı hastaların tümör hücrelerinde de pozitif boyanma göstermesi yeni oluşan damarların tespit edilebilmesini zorlaştırmıştır. Tümör tipine göre VEGFR2 ekspresyonu ile tespit edilen ortalama MY iki grupta farklılık göstermemiştir. Çalışmamızda CD31, VEGFR2 ve endoglin ekspresyonu sonucu elde edilen ortalama MY'ye göre olgulara ait klinikopatolojik özellikler (tümör çapı, lokalizasyon, anjiolenfatik invazyon, plevral invazyon, lenf nodu metastazı, uzak metastaz, tümör evresi, lokal nüks ve sağkalım) karşılaştırıldığında istatistiksel olarak anlamlı ilişkiye ulaşamadık. Tümör tipine göre ise yalnızca endoglin ekspresyonu ile elde edilen ortalama MY'nin SHK grubunda istatistiksel olarak artış gösterdiğini tespit ettik.

Dolaşımdaki serum endoglin düzeyinin farklı tümörlerde metastatik hastalığın varlığı ile korele olduğu belirtilmektedir. KHDAK [9], serviks kanseri [7], prostat kanseri [6], meme kanseri [8, 10] dahil olmak üzere yapılan araştırmalarda yüksek endoglin ekspresyonunun kötü prognozun önemli bir göstergesi olduğu gösterilmiştir. Ayrıca flow sitometrik yöntemle gerçekleştirilen bir çalışmada akut myeloid Iösemi hastalarının takip ve tedavi kararlarını optimize etmeye hizmet edebilecek yeni bir prognostik belirteç olarak endoglin ekspresyonunun tanımlanabileceği belirtilmiştir [37]. Szubert ve ark.'nın çalışmasında [38] ise serum endoglin düzeyinin malign yumurtalık tümörlerinde iyi huylu yumurtalık tümörlerine kıyasla düşük olduğu bildirilmiştir. Bizim çalışmamız da Szubert ve ark.'nın çalışmasını [38] destekler niteliktedir. Çalışmamıza gönüllü olarak katılan 26 KHDAK'li hastaların ortalama serum endoglin seviyeleri 12,42 $\pm 10,6$ iken kontrol grubunda $12,61 \pm 13,12$ olarak tespit edilmiştir. Bu sonuçlara göre serum endoglin seviyesinin KHDAK hastaları ve kontrol grubu arasında istatistiksel olarak anlamlı olmadığını gözledik.
Yapılan çalışmalarda farklı tümör tiplerinde endoglin, CD31 ve VEGFR2 ekspresyonlarında farklı sonuçlar elde edilmiş olduğu görülmektedir. Çalışmamızda VEGFR2'nin tümör içi ve dışı damar duvarları ve bazı hastaların tümör hücrelerinde pozitiflik göstermiş olması ve CD31'in nonspesifik boyanmasına bağlı olarak MY'nin tespit edilmesinde güçlükler yaşanmasına neden olmuştur. Endoglinin intratümöral bölgede küçük kan damarlarını spesifik boyaması sonucu anjiogenezin tespit edilmesinde prognostik bir belirteç olarak kullanılabileceğini düşünmekteyiz. Bununla birlikte çalışma gruplarımızın homojen olmaması ve vaka sayımızın az olması çalışmamızın kısıtlılıkları arasında yer almaktadır. Bu nedenle primer tümör veya metastazlarda endoglin, CD31 ve VEGFR2 ekspresyonlarının değerlendirilebileceği daha fazla hastanın dahil edilebildiği prospektif çalışmalara intiyaç olduğunu düşünmekteyiz.

Çıkar ilişkisi: Yazarlar çıkar ilişkisi olmadığını beyan eder.

\section{Kaynaklar}

1. Jain RK. Normalizing tumor vasculature with antiangiogenetic therapy. Nat Med 2001;7:987-989. https://doi.org/10.1038/nm0901-987

2. Shields TW. Pathology of Careinoma of The Lung. In Shields TW (ed): General Thoracic Surgery, 6th ed. Lippincott Willams\&Wilkins; Philadelphia,2005;1455-1481.

3. Carmeliet $P$, Jain RK. Molecular mechanisms and clinical applications of angiogenesis. Nature 2011;473:298307. https://doi.org/10.1038/nature10144

4. Lima $A B$, Macedo $L T$, Sasse AD. Addition of bevacizumabto chemotherapy in advanced nonsmall cell lung cancer: a systematic review and meta-analysis. PLoS One 2011;6:e22681. https://doi. org/10.1371/journal.pone.0022681

5. Folkman J. What is the evidence that tumors are angiogenesis dependent? J Natl Cancer Inst 1990;82:4-6. https://doi.org/10.1093/jnci/82.1.4

6. Wikström P, Lissbrant IF, Stattin P, Egevad L, Bergh A. Endoglin (CD105) is expressed on immature blood vessels and is a marker for survival in prostate cancer; Prostate 2002;51:268-275. https://doi.org/10.1002/ pros. 10083

7. Brewer CA, Setterdahl JJ, Li MJ, Johnston JM, Mann $\mathrm{JL}$, McAsey ME. Endoglin expression as a measure of microvessel density in cervical cancer. Obstet Gynecol 2000;96:224-228. https://doi.org/10.1016/S00297844(00)00864-4 
8. Kumar S, Ghellal A, Li C, et al. Breast carcinoma: vascular density determined using CD105 antibody correlates with tumor prognosis. Cancer Res 1999;59:856-861.

9. Tanaka F, Otake Y, Yanagihara K, et al. Evaluation of angiogenesis in non-small cell lung cancer: comparison between Anti-CD34 antibody and anti-CD105 antibody. Clin Cancer Res 2001;7:3410-3415.

10. Charpin Taranger C, Dales JP, Garcia S, et al. The immunohistochemical expression of CD105 is a marker for high metastatic risk and worse prognosis in breast cancers. Bull Acad Natl Med 2003;187:1129-1145.

11. DeLisser HM, Baldwin HS, Albelda SM. Platelet endothelial cell adhesion molecule 1 (PECAM-1/ CD31): a multifunctional vascular cell adhesion molecule. Trends Cardiovasc Med 1997;7:203-210. https://doi.org/10.1016/S1050-1738(97)00049-2

12. Matsumura T, Wolff K, Petzelbauer P. Endothelial cell tube formation depends on cadherin 5 and CD31 interactions with filamentous actin. J Immunol 1997;158:3408-3416.

13. Pinter E, Barreuther M, Lu T, Imhof BA, Madri JA. Platelet-endothelial cell adhesion molecule-1 (PECAM-1/CD31) tyrosine phosphorylation state changes during vasculogenesis in the murine conceptus. Am J Pathol 1997;150:1523-1530.

14. Fernández Martín L, Marcos Ramiro B, Bigarella CL, et al. Crosstalk between reticular adherens junctions and platelet endothelial cell adhesion Molecule-1 regulates endothelial barrier function. Arteriosclerosis, Thrombosis, and Vascular Biology 2012;32:90-102. https://doi.org/10.1161/ATVBAHA.112.252080

15. Prior BM, Yang HT, Terjung RL. What makes vessels grow with exercise training? J Appl Physiol 2004;97:1119-1128. https://doi.org/10.1152/ japplphysiol.00035.2004

16. Carmeliet $P$. VEGF as a key mediator of angiogenesis in cancer. Oncology 2005;69:4-10. https://doi. org/10.1159/000088478

17. Travis WD, Brambilla E, Burke AP, Marx A, Nicholson AG. (Eds.), WHO Classification of Tumours of the Lung, Pleura, Thymus and Heart (4th ed.), International Agency for Research on Cancer, Lyon, France;2015.

18. Weidner N. Current pathologic methods for measuring intratumoral microvessel density within breast carcinoma and other solid tumors. Breast Cancer Res Treat 1995;36:169-180. https://doi.org/10.1007/ BF00666038

19. Travis WD, Brambilla E, Hermelink HKM, Haris CC. Pathology and Genetics of Tumors of the Lung, Plevra, Thymus and Heart, Lyon: IARC Press; 2004.

20. Moran CA. Pulmonary adenocarcinoma: the expanding spectrum of histologic variants. Arch Pathol Lab Med 2006;130:958-962. https://doi.org/10.1043/15432165(2006)130[958:PATESO]2.0.co;2
21. Bozkurt B, Selçuk ZT, Fırat P, Kalyoncu AF, Artvinli M. 1972-2002 döneminde Hacettepe Üniversitesi Tıp Fakültesi Hastanesinde akciğer kanseri tanısı konulan hastaların histolojik ve epidemiyolojik değerlendirilmesi. Toraks Dergisi 2004;5:148-153.

22. Sulu E, Damadoğlu E, Nergiz S, ve ark. Primer akciğer kanserinde tümör tipi ve cinsiyet dağılımı değişiyormu? 2004 yılı sonuçlarının daha önceki yıllar ile karşılaştırılması. Tüberküloz ve Toraks Dergisi 2007;55:59-63.

23. Bochner BH, Cote RJ, Weidner N, et al. Angiogenesis in bladder cancer: relationship between microvessel density and tumor prognosis. J Natl Cancer Inst 1995;87:1603-1612. https://doi.org/10.1093/ jnci/87.21.1603

24. Mineo TC, Ambrogi $\mathrm{V}$, Baldi $\mathrm{A}$, et al. Prognostic impact of VEGF, CD31, CD34, and CD105 expression and tumour vessel invasion after radical surgery for IB-IIA non-small cell lung cancer. J Clin Pathol 2004;57:591597. http://dx.doi.org/10.1136/jcp.2003.013508

25. Ciocâlteu A, Săftoiu A, Pirici D, et al. Tumor neoangiogenesis detection by confocal laser endomicroscopy and anti-CD105 antibody: pilot study. World J Gastrointest Oncol 2015;7:361-368. https://doi.org/10.4251/wjgo.v7.i11.361

26. Mitselou A, Galani V, Skoufi U, Arvanitis DL, Lampri E, loachim E. Syndecan-1, Epithelial-Mesenchymal Transition Markers (E-cadherin/ $\beta$-catenin) and Neoangiogenesis-related Proteins (PCAM-1 and Endoglin) in Colorectal Cancer. Anticancer Res 2016;36:2271-2280.

27. Moghaddam NA, Mahsuni P, Taheri D. Evaluation of Endoglin as an Angiogenesis Marker in Glioblastoma. Iran J Pathol 2015;10:89-96.

28. Tanno S, Ohsaki Y, Nakanishi K, Toyoshima E, Kikuchi K. Human small cell lung cancer cells express functional VEGF receptors, VEGFR-2 and VEGFR-3. Lung Cancer 2004;46:11-19. https://doi.org/10.1016/j. lungcan.2004.03.006

29. Wu W, Onn A, Isobe T, et al. Targeted therapy of orthotopic human lung cancer by combined vascular endothelial growth factor and epidermal growth factor receptor signaling blockade. Mol Cancer Ther 2007;6:471-483. https://doi.org/10.1158/1535-7163. mct-06-0416

30. Bonnesen B, Pappot H, Holmstav J, Skov BG. Vascular endothelial growth factor $A$ and vascular endothelial growth factor receptor 2 expression in non-small cell lung cancer patients: relation to prognosis. Lung Cancer 2009;66:314-318. https://doi.org/10.1016/j. lungcan.2009.02.013

31. Pajares MJ, Agorreta J, Larrayoz M, et al. Expression of tumor-derived vascular endothelial growth factor and its receptors is associated with outcome in early squamous cell carcinoma of the lung. J Clin Oncol 2012;30:1129-1136. https://doi.org/10.1200/ jco.2011.37.4231 
32. Holzer TR, Fulford AD, Nedderman DM, et al. Tumor cell expression of vascular endothelial growth factor receptor 2 is an adverse prognostic factor in patients with squamous cell carcinoma of the lung. PLoS One 2013;8:e80292. https://doi.org/10.1371/journal. pone.0080292

33. Seto T, Higashiyama M, Funai H, et al. Prognostic value of expression of vascular endothelial growth factor and its flt-1and KDR receptors in stage I non-small-cell lung cancer. Lung Cancer 2006;53:91-96. https://doi. org/10.1016/j.lungcan.2006.02.009

34. Carrillo de Santa Pau E, Arias FC, Caso Peláez E, et al. Prognostic significance of the expression of vascular endothelial growth factors $A, B, C$, and $D$ and their receptors $\mathrm{R} 1, \mathrm{R} 2$, and $\mathrm{R} 3$ in patients with nonsmall cell lung cancer. Cancer 2009;115:1701-1712. https://doi. org/10.1002/cncr.24193

35. Smith NR, Baker D, James NH, et al. Vascular endothelial growth factor receptors VEGFR-2 and VEGFR-3 are localized primarily to the vasculature in human primary solid cancers. Clin Cancer Res 2010;16:35483561. https://doi.org/10.1158/1078-0432.ccr-09-2797

36. Devery AM, Wadekar R, Bokobza SM, Weber AM, Jiang Y, Ryan AJ. Vascular endothelial growth factor directly stimulates tumour cell proliferation in non-small cell lung cancer. Int J Oncol 2015;47:849-856. https:// doi.org/10.3892/ijo.2015.3082

37. Kauer J, Schwartz K, Tandler C, et al. CD105 (Endoglin) as negative prognostic factor in AML. Sci Rep 2019;9:18337. https://doi.org/10.1038/s41598019-54767-x

38. Szubert S, Moszynski R, Michalak S, Nowicki M, Sajdak S, Szpurek D. The associations between serum VEGF, bFGF and endoglin levels with microvessel density and expression of proangiogenic factors in malignant and benign ovarian tumors. Microvasc Res 2016;107:9196. https://doi.org/10.1016/j.mvr.2016.06.002

Etik kurul onayı: Pamukkale Üniversitesi Girişimsel Olmayan Klinik Araştırmalar Etik Kurulu'nun 31.01.2017 tarih ve 02 sayılı kararı ile onay alınmıştır.

Destek: Pamukkale Üniversitesi, Bilimsel Araştırma Projeleri Koordinasyon Birimi tarafından (Proje No:2017SABE003) desteklenmiştir.

\section{Yazarların makaleye katkıları}

Literatür taraması, araştırmanın planlanarak histopatolojik değerlendirmesi H.Ç., F.B., çalışmada yer alan hastaların takibi ve değerlendirmesi S.B.Ö. ve A.K., biyokimyasal analizi Y.E. tarafından gerçekleştirilmiştir.
Çalışmamız, 08-10 Nisan 2021 tarihinde düzenlenen 4. Uluslararası Sağlık Bilimleri ve Yaşam Kongresi'nde sözlü bildiri olarak sunulmuştur. 